\title{
Application of SWAT model to estimate the annual runoff and sediment of Duhok reservoir watershed
}

\author{
M.E. Mohammad \\ Department of Dams and Water Resources Engineering, University of Mosul, Mosul, Iraq \\ N. Al-Ansari \& S. Knutsson \\ Department of Civil, Environmental and Natural Resources Engineering, Luleå University of Technology, Luleå, \\ Sweden
}

\begin{abstract}
Estimation of runoff volume and sediment load is a problem that directly affects the performance of dams due to the reduction in the storage capacity of their reservoirs and their effect on dam efficiency and operation schedule. The simulation models can be considered for evaluation of sediment potential if the continuous field measurements are not available. Soil and Water Assessment Tool (SWAT) was applied to estimate the annual runoff volume and sediment load for Duhok Dam Reservoir in north of Duhok/Iraq for the period 1988-2011. The estimated annual runoff volume varied from 2.6 to $34.7 \mathrm{MCM}$. Those values are affected by rainfall depth, intensity and runoff coefficient, while the annual runoff coefficient for the studied area ranged from 0.06 to 0.33 (average is 0.19 ) causing an average runoff volume of $14.3 \mathrm{MCM}$. The sediment routing indicated that the values of sediment yields varied from 50 to $1400 \mathrm{t} / \mathrm{km}^{2} /$ year depending on sub basin properties. The average annual sediment load from the whole watershed was $124.6^{*} 10^{3}$ ton. The estimated total sediment arrived to Duhok Reservoir for the considered period $1988-2011$ was about $2.99 * 10^{6}$ ton.
\end{abstract}

\section{INTRODUCTION}

Sediments are one of the major problems for the operation of dams. They reduce the storage capacity of the reservoir and they can cause serious problems concerning the operation and stability of the dam (Srinivasan 1996). One of the important factors in reservoir design and operation is the sedimentation problem. Sediment delivered to the reservoir comes from two main sources. The first source is the main river entering the reservoir and the second source is the valleys on both sides of the reservoir. Due to the importance of the problem several empirical methods were developed and later modeling techniques were adopted (U.S. Department of Interior 1972). Several types of models are used to predict sediment load among these (Srinivasan et al. 1998; Fernandez et al. 2003; Kim 2006; Yüksel et al. 2008; Baigorria \& Romero 2007; Engda 2009; Gitas et al. 2009;, Nangia 2010; Jain 2010). Kim et al. 2008 developed the Soil and Water Assessment Tool (SWAT) ArcView GIS Patch II for steep slope watersheds. SWAT is a physically based model was developed to simulate and predict the runoff, sediment load, and agricultural chemical yields for large and complex watersheds having different soil type (Ashagre 2009).
Santos et al. 2010 applied these models and got good results on Apucaraninha River watershed in southern of Brazil. Doughlas-Mankin et al. 2010 reviewed and introduced a number of selected papers which present and applied the SWAT (soil and water assessment tool). Other researchers (Jain 2010; Betrie et al, 2011; Mohammad et al. 2012; Shawul et al. 2013) used the SWAT model to predict sediment transport and generally, the overall results of the SWAT model were reasonable.

In this research the SWAT model was applied to evaluate the total sediment load accumulated in its reservoir since its operation in 1988 untill 2011. There are number of studies which were carried out concerning Duhok Dam and its reservoir. Mustafa and Noori 2013 applied the remote sensing technique and geographical information system to assess the change in water surface area of Duhok Dam reservoir for the period 2001 to 2012. Issazadeh \& Govay 2014 applied Artificial Neural Network (ANN) of three layer back propagation to model the sediment load of Duhok Dam. The measured time series data of flow for the period 2010-2011 were considered as input, while the sediment loads represents the results of model output. Sulaiman 2010 applied a technique to estimate the sediment concentration at the outlet of Duhok 
Reservoir watershed. The method was based on runoff turbidity and sediment concentration sampling data at watershed outlet for the period 2008-2009 to estimate the annual sediment load. Mohammed 2010 estimate the runoff and sediment load from the all sub watersheds of Duhok Dam (Bajlor, Sindor, Linava and Dole Germava). The estimated flow volume for the period Nov 1978 to Oct 1979 was $12^{*} 10^{6} \mathrm{~m}^{3}$, while the maximum suspended load for the period from Dec 1978 to Feb 1980 was $5 \mathrm{~kg} / \mathrm{m}^{3}$. The estimated sediment load indicates that they have a significant effect on dam storage capacity. Mohammed, 2013, applied the approach of remote sensing and geographical information system (GIS) to analyze the urban growth and land use change in Duhok city for the period 1998, 2007 and 2011. The results indicated that there is an increase in the urban area while cultivated areas decreased for the considered period. Previous studies concerning Duhok Reservoir deal with runoff, sediment concentration and load or the factors affecting them for a specific period. None of the previous studies was concerned with estimating the total sediment load accumulated after more than twenty years of dam operation. It is noteworthy to state that Iraq is suffering from water shortage problems now (Al-Ansari 1998; Al-Ansari 2013; Al-Ansari \& Knutsson 2013; Al-Ansari et al. 2014; Al-Ansari et al. 2015) and it is very important to know the actual capacity of the reservoirs to attain prudent management of water resources in the country. The objective of study is to estimate the runoff volume and sediment load of Duhok Dam Reservoir from the beginning of dam operation 1988 to 2011 based on SWAT model.

\section{STUDY AREA}

The study area is the watershed of Duhok Dam Reservoir. Duhok Dam is an earth fill dam located at $2 \mathrm{Km}$ north of Duhok City. The dam height is $64 \mathrm{~m}$, length $613 \mathrm{~m}$ and crest width $9 \mathrm{~m}$. The storage capacity is $52 * 10^{6} \mathrm{~m}^{3}$ including $47.51 * 10^{6} \mathrm{~m}^{3}$ live storage and $4.3910^{6} \mathrm{~m}^{3}$ dead storage. The dam was built to provide for irrigation of agricultural areas of about 4300 hectare, supply water for Duhok City as well as recreation area. The watershed area of Duhok Dam is about $130 \mathrm{~km}^{2}$ bounded by the coordinates $36^{\circ} 51^{\prime} 20^{\prime \prime} \mathrm{N}, 37^{\circ} 01^{\prime} 00^{\prime \prime} \mathrm{N}, 42^{\circ} 50^{\prime}$ $30^{\prime \prime} \mathrm{E}$ and $43^{\circ} 05^{\prime} 50^{\prime \prime} \mathrm{E}$. It is divided into four sub watersheds (Dolee Garmava, Sindor, Bajlor and Per Omara) as shown in Figure 1. The areas of the sub watersheds range from 86.5 to $5 \mathrm{~km}^{2}$, while the slopes are between 19.8 to $25.7 \%$. The different geometric properties of the watersheds are given in Table 1.

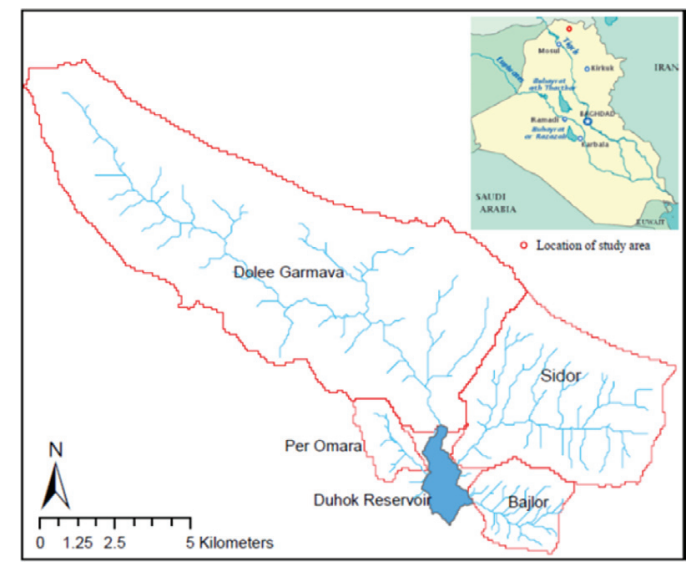

Figure 1. Duhok Dam Reservoir and its sub watersheds.

Table 1. Geometric properties of the sub-watersheds of Duhok Dam Reservoir.

\begin{tabular}{lrrrr}
\hline & Area & Length & $\begin{array}{l}\text { Average } \\
\text { slope }\end{array}$ & $\begin{array}{l}\text { Mean } \\
\text { elevation }\end{array}$ \\
\cline { 2 - 5 } Watershed & $\left(\mathrm{km}^{2}\right)$ & $(\mathrm{Km})$ & $\%$ & (m.a.s.l) \\
\hline Dolee Garmava & 86.5 & 17.6 & 19.8 & 8891 \\
Sindor & 30.3 & 7.6 & 17.7 & 855 \\
Bajlor & 8.1 & 3.1 & 23.3 & 825 \\
Per Omara & 5.0 & 2.9 & 25.7 & 776 \\
\hline
\end{tabular}

The minimum, maximum and average annual precipitation depth of Duhok Station for the considered period is about 284, 880 and $540 \mathrm{~mm}$ respectively. Based on soil map of Iraq (Buringh 1960) and soil samples analysis of studied area (Mohammed 2010; Mohammad et al. 2012) the soil type map of study area was prepared. The results of analysis indicated that the soil texture of the area is sandy clay loam, silty clay loam, clay loam, and loam.

The land use and land cover map of study area was prepared based on Landsat 7 ETM+ images and field study of the watershed. The overall land use and land cover consist of $23.8 \%$ forest land, $16.7 \%$ open land, $13.6 \%$ grass land, $13.4 \%$ open land with tree, $13.3 \%$ waste land rock, $10.8 \%$ cultivated land and $8.4 \%$ rock land.

\section{DESCRIPTION OF SWAT MODEL}

Soil and Water Assessment Tool (SWAT) is a continuous simulation model developed by the USDAAgricultural Research Service. It is a physically 
based model to estimate runoff, nutrient losses, chemical and sediment transport within the Watershed scale for daily time step (Arnold et al. 1998). The surface runoff estimation in the model can be done by two methods, the Soil Conservation Service method (USDA-SCS) sometimes called Curve Number (CN) method (USDA-SCS, 1972) and the Green and Ampt method (Green \& Ampt 1991 as quoted by Neitsch et al. 2009). The daily precipitation data is required to estimate the surface runoff by SCS curve number method, the curve number estimation is depends on certain soil type (permeability), land use and antecedent soil moisture conditions. The Green and Ampt infiltration method estimates the infiltration rate based on hydraulic conductivity and metric potential of wetting front, so it requires a sub-daily precipitation data.

The SCS curve number method is an empirical method to estimate the surface runoff based on studies of different rainfall-runoff relationships for small rural watersheds, then developed for different types of soils and land use (Neitsch et al. 2009). The equation of estimating the runoff depth in SCS curve number method is:

$\mathrm{Q}_{\text {surf }}=\frac{\left(\mathrm{R}_{\mathrm{day}}-\mathrm{I}_{\mathrm{a}}\right)^{2}}{\left(\mathrm{R}_{\mathrm{day}}-\mathrm{I}_{\mathrm{a}}+\mathrm{S}\right)}$

Where:

$\mathrm{Q}_{\text {surf }}=$ accumulated runoff $(\mathrm{mm})$,

$\mathrm{R}_{\text {day }}=$ daily rainfall depth, and

$\mathrm{S}=$ retention parameter.

The retention parameter varies depending on soil type, slope, land cover and management and antecedent moisture conditions, it is equal to:

$\mathrm{S}=25.4\left(\frac{1000}{\mathrm{CN}}-10\right)$

Where:

$\mathrm{CN}=$ curve number for normal hydrological condition.

The initial abstraction (Ia) is considered equal to $0.2 \mathrm{~S}$, so the equation (1) becomes in the following form:

$\mathrm{Q}_{\text {surf }}=\frac{\left(\mathrm{R}_{\mathrm{day}}-0.2 \mathrm{~S}\right)^{2}}{\left(\mathrm{R}_{\mathrm{day}}+0.8 \mathrm{~S}\right)}$ for $\mathrm{R}_{\mathrm{day}}>0.2 \mathrm{~S}$

The curve number for normal moisture condition (field capacity) is identified based on soil type and land use, then it is modified based on antecedent moisture condition.

The sediment load estimation in SWAT model was executed for each hydrological response unit
(HRU) divided into two phases, overland phase and channel flow. The Modified Universal Soil Loss Equation was considered to estimate the erosion and sediment load from rainfall and overland flow. Then the simple form of stream power theory was applied to estimate the channel sediment routing including degradation or deposition. The channel bed and bank erosion will occur when stream flow transport capacity is greater than sediment load (coming from upstream region) at that reach and flow shear stress is greater than the stress required to detach the soil particles. While the deposition will occur in the case that sediment load is greater than transport capacity, the rate of sediment deposition depends on the fall velocity of particles.

\section{MODEL CALIBRATION}

In order to apply the model to estimate the runoff and sediment load entering the Duhok Dam from the watershed, the model was calibrated for both runoff and sediment concentration as a first step to ensure the model ability. The required input data of the model included: description of watershed topography as a Digital Elevation Model (DEM) and daily readings of climate data (precipitation, wind, maximum and minimum temperature, solar radiation and relative humidity). Duhok Dam and Duhok weather stations were considered for that. In addition, the other required input data were the soil type and land cover and use as digital maps.

The available daily precipitation data were taken from Duhok Dam and Duhok stations (the nearest stations to study area). Then, the SCS curve number method was considered in this study. The available measured runoff data are the accumulated monthly values for the rain season 2008-2009 as presented by Sulaiman, 2010. These data were considered for model calibration. The effective parameters for flow calibration were the curve number $(\mathrm{CN})$ for each soil type, hydraulic conductivity of the channel, hydraulic conductivity of the soil and Manning's roughness coefficient for over land flow and channel flow. These parameters were adjusted within allowable limits in the calibration process to obtain the best results. Figure 2 shows the observed and optimal predicted values by SWAT model for total monthly runoff. One of the main differences in runoff volume at the measured value of $490.5^{*} 10^{3} \mathrm{~m}^{3}$ is that the predicted value was zero. This difference is attributed to the fact that the total monthly rainfall in that month did not exceed $5 \mathrm{~mm}$.

As far as the statistical criteria are concerned it involved the determination of the coefficient $\left(\mathrm{r}^{2}\right)$ and Nash-Sutcliffe model efficiency (Eff.) where they were considered for model output evaluation. 


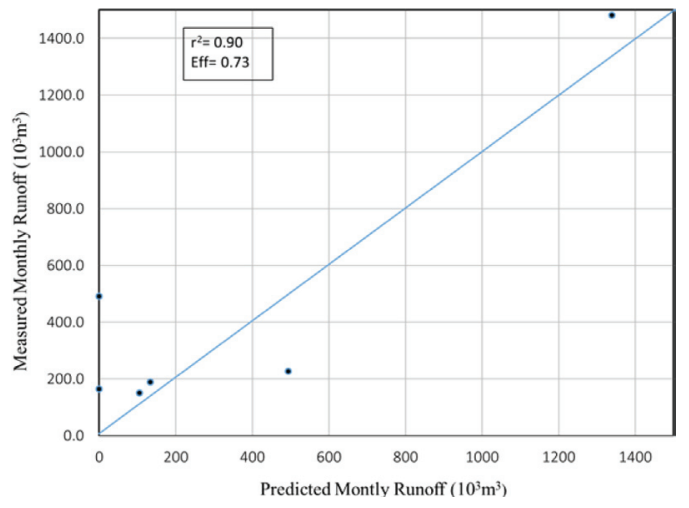

Figure 2. Observed and predicted monthly runoff volume.

The best values obtained were 0.94 and 0.90 for both parameters respectively, indicating a good model performance. After observing acceptable values of runoff volumes, the second step was the calibration of SWAT model for sediment load (concentration) which was performed against observed values (Mohammed, 2010). The effective parameters for sediment load calibration were land cover, channel cover factor $(\mathrm{C})$ and support practice factor $(\mathrm{P})$ for Universal Soil Loss equation (USLE), while channel cover and erodibility factor were used for both linear and exponent parameters of channel sediment load routing equation,. By applying the manual calibration tool in SWAT model, those parameters which can affect the sediment load concentration were changed within the allowable limit of each one, while the same statistical criteria, determination coefficient $\left(\mathrm{r}^{2}\right)$ and Nash-Sutcliffe model efficiency (Eff.) for model performance evaluation were considered. Figure 3 shows the observed and predicted sediment concentration at different days of the rainy season 2008-2009. The best values of the statistical criteria for the determination of coefficient and Nash-Sutcliffe model efficiency were 0.94 and 0.84 respectively.

\section{MODEL VALIDATION}

The model was calibrated for both runoff and sediment load based on manual calibration tools by electing the best values of the parameters effecting both runoff and sediments. The results of statistical criteria indicated acceptable values relative to the measured values. Validation of the model was a necessity before its application. Due to limited available measured data for both runoff and sediments, the model was validated based on available measured annual sediment load data presented by

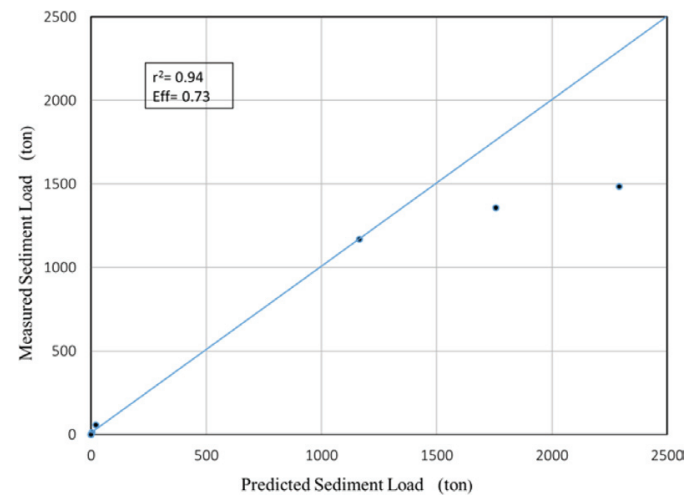

Figure 3. Observed and predicted sediment concentration.

Mohammed, 2010. Table 2 shows the measured and predicted sediment loads based on SWAT model. The resultant statistical criteria, (Eff.) correlation coefficient $\left(\mathrm{r}^{2}\right)$ and model efficiency are 0.74 and 0.83 respectively, indicating acceptable model performance.

\section{RESULTS AND DISCUSSION}

The soil and water assessment tool (SWAT) was applied to estimate the runoff volume and sediment load from the watershed of Duhok Dam Reservoir. The considered period for simulation was from the year of dam operation in 1988 to 2011. The SWAT model was applied for daily simulation based on available data of daily rainfall, maximum and minimum daily temperature, wind speed, relative humidity and solar radiation. The resultant maximum and minimum annual runoff volume from the four basins was 34.7 and 2.6 MCM respectively while the average value for considered period was 14.3 MCM. Figure 4 shows the annual runoff volume from 1988 to 2011. As it is well known, the values of surface runoff depend not only on rainfall depth, but also the rainfall distribution within the year, rainfall intensity, soil water content and land cover. To describe the variation of annual surface runoff coefficient and annual rainfall depth, Figure 5 shows those values for the considered period. The minimum runoff coefficient value was 0.066 for the year 1990, where the rainfall depth $(305 \mathrm{~mm})$ was less than average value $(540 \mathrm{~mm})$. That is attributed to annual rainfall depths of less than the average in years 1989 (320 mm) and 1990 (305 mm).

The successive two years of relatively low rainfall depth less than the average values had affected the water content in the soil and this was reflected 
Table 2. Measured and predicted sediment loads based on SWAT model.

\begin{tabular}{|c|c|c|c|c|}
\hline Year & $\begin{array}{l}\text { Measured } \\
\text { sediment } \\
\text { load } \\
10^{5} \mathrm{~m}^{3}\end{array}$ & $\begin{array}{l}\text { Predicted } \\
\text { sediment } \\
\text { load } \\
(\mathrm{SWAT}) \\
10^{5} \mathrm{~m}^{3}\end{array}$ & $\begin{array}{l}\text { Determination } \\
\text { coefficient } \\
\mathrm{r}^{2}\end{array}$ & $\begin{array}{l}\text { Model } \\
\text { efficiency } \\
\%\end{array}$ \\
\hline 1997 & 1.70 & 1.41 & 0.98 & 60 \\
\hline 2001 & 0.23 & 0.86 & & \\
\hline 2003 & 1.40 & 1.34 & & \\
\hline
\end{tabular}

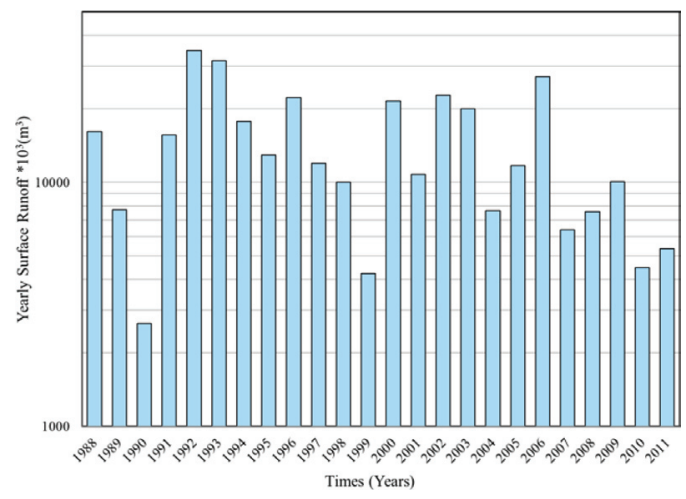

Figure 4. Annual runoff volume from Duhok Reservoir Watershed for period 1988-2011.

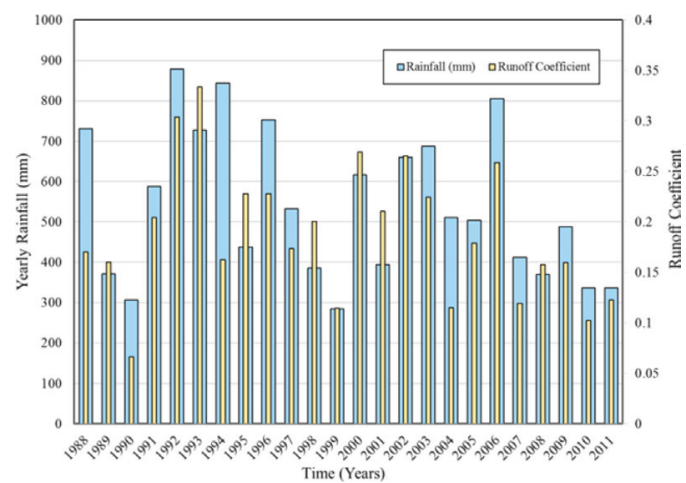

Figure 5. Yearly rainfall and runoff coefficient of Duhok Reservoir watershed.

on the infiltration rate and runoff coefficient especially in the second year. The maximum rainfall recorded in the area was in 1992 where it reached $879 \mathrm{~mm}$. For this reason, the maximum runoff coefficient of 0.33 was noticed in 1993 where the rainfall depth reached $727 \mathrm{~mm}$. The estimation of runoff volume is an important factor for operation of different hydraulic structures such as dams and reservoirs, where it affects the storage volume and operation schedule.

The sediment concentration and total annual sediment load was also estimated for the four valleys of Duhok Dam Reservoir. The sediment load depends on rain properties, runoff volume and watershed properties. For certain watersheds, the rainfall depth and intensity effects the detachment of soil particles and infiltration rate, while the runoff volume carries the detached load and pickup more sediment. The total annual load predicted by SWAT model for the years 1988-2011 are shown in Figure 6. The maximum and minimum annual sediment load was about $2.9 * 10^{5}$ and $0.29 * 10^{5}$ tons respectively from the four sub watersheds. The average annual value for the considered period is about 960 ton $/ \mathrm{km}^{2}$. The sediment per unit area varies between the watersheds depending on land cover, soil type and land topography. Also for the hydrological response units (sub-basins) that each one has common properties. Based on the results of sediment yields model for each hydrological response units, a map of average annual sediment detachment yields for each watershed of studied area (Dolee Garmava, Sindor, Bajlor and Per Omara) was presented as shown in Figure 7. Those maps gives an idea of the sub basin which considered having high percent of sediment load contribution in comparison with other sub basins. A different methods of soil stabilization can applied the to reduce the sediment yield in case that load is greater than considered values in design of reservoir probable live. The annual sediment load varied from 50 to 1400 ton $/ \mathrm{km}^{2}$ as shown in Figure 7, depending on sub basin topography, soil type and land cover. One of the most important factor in sediment detachment and transportation is the land topography and slope. For Dolee Garmava watershed (Figure 7(a)) having average slope of 19.8\%, the frequency analysis of sediment data indicated

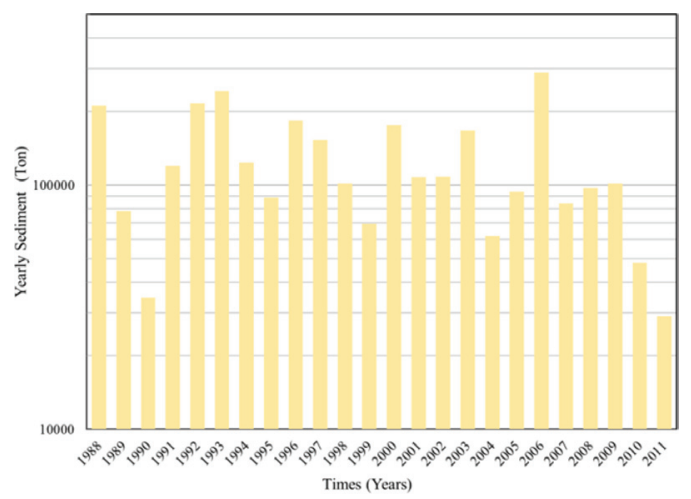

Figure 6. Yearly sediment load of Duhok Reservoir watershed. 


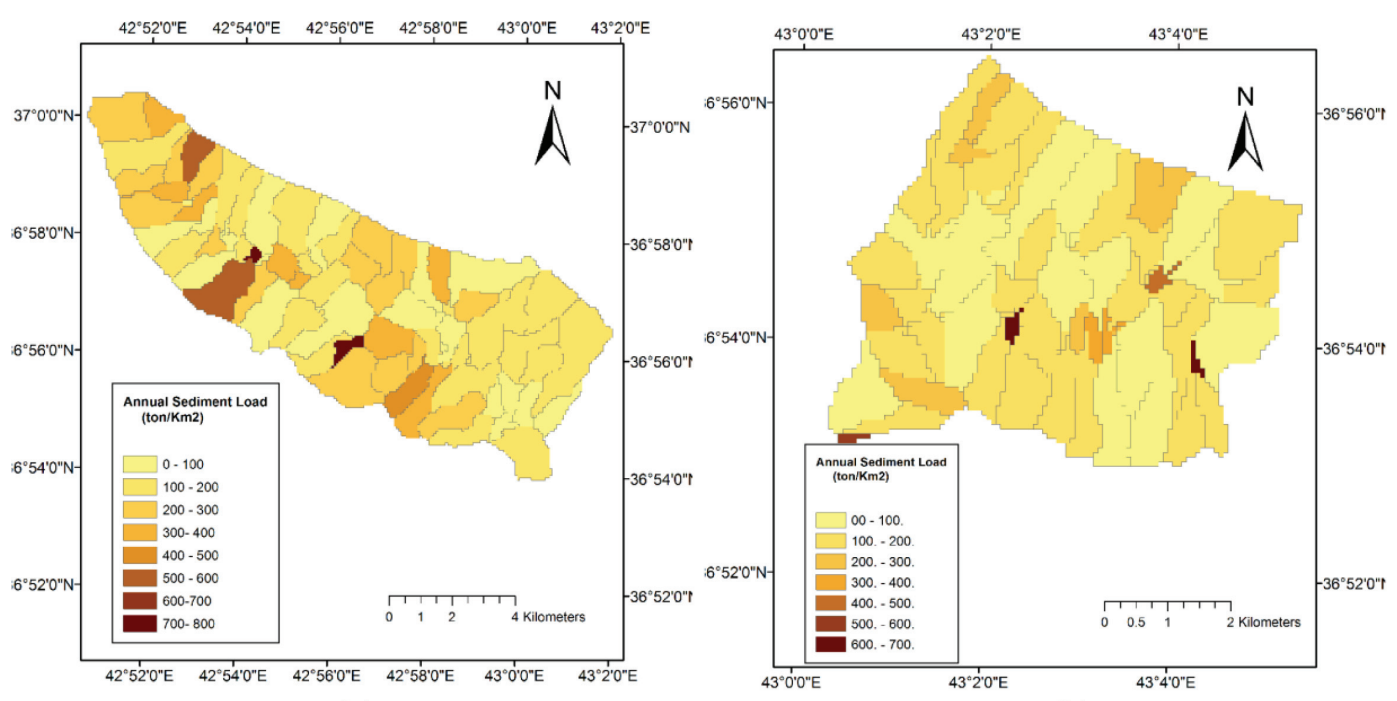

(a)

(b)

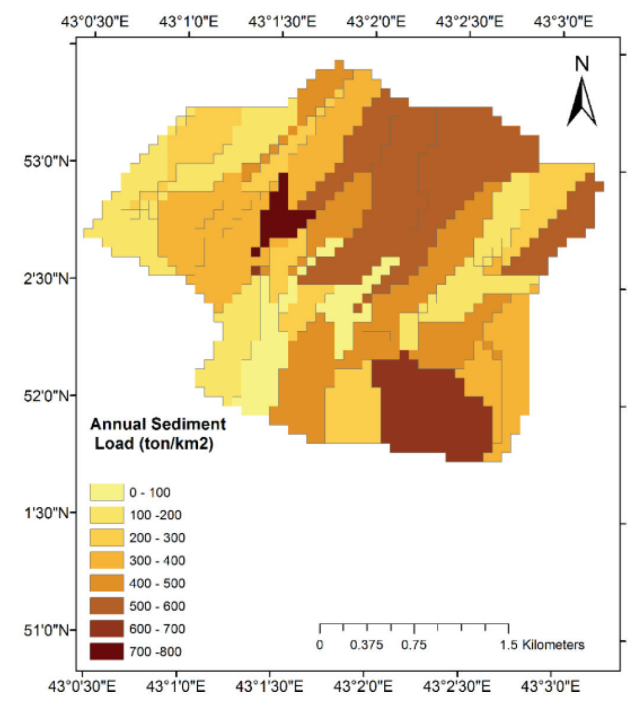

(c)

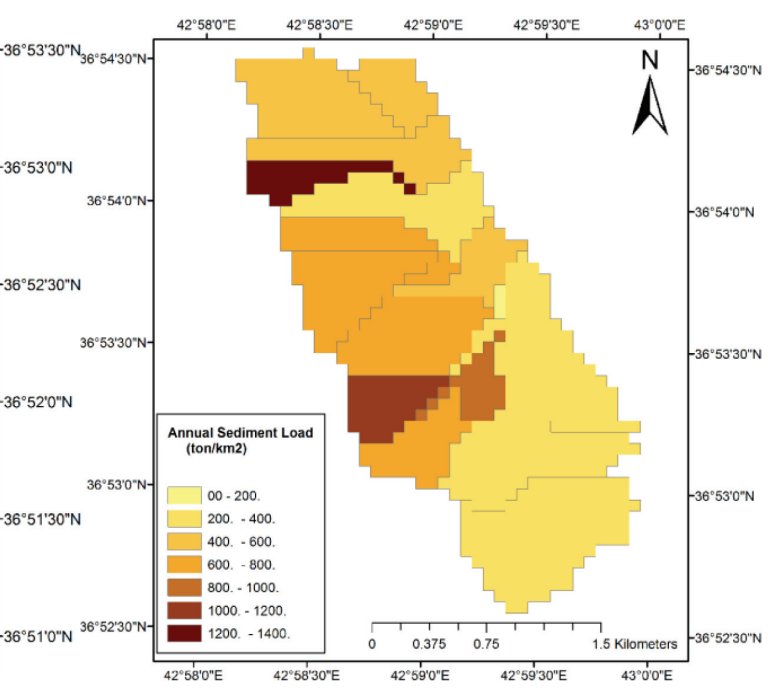

(d)

Figure 7. Average annual sediment of sub basins of Duhok Dam catchment area (a) Dolee (b) Garmava Sindor (c) Bajlor.

that the percent of sediment load concentration was $50-100$ and $100-600$ ton/year/ $/ \mathrm{km} 2$ for $60 \%$ and $35 \%$ of the area of that catchment respectively. For Sindor watershed average slope of $19.8 \%$, the frequency analysis of sediment data indicated that the percent of sediment load concentration was $50-100$ and $100-600$ ton/year $/ \mathrm{km}^{2}$ for $60 \%$ and $35 \%$ of the area of that catchment respectively. For Sindor watershed (Figure 7(b)), having average slope of $17.7 \%, 75 \%$ of the basin area has a sediment load of $50-200$ ton $/$ year $/ \mathrm{km}^{2}$, while the remaining $25 \%$ is contributed higher sediment load.
For Bajlor watershed (Figure 7c), having average slope of $23.3 \%$, about $50 \%$ of the basin contributes sediment load concentration of $50-400$ ton/ year $/ \mathrm{km}^{2}$ and $45 \%$ between $400-800$ ton $/$ year $/ \mathrm{km}^{2}$, while for Per Omara watershed, having average slope of $25.7 \%$, only $6 \%$ of the area contributes sediment load of $50-200$ ton/year $/ \mathrm{km}^{2}$, while $80 \%$ of the area contributes sediment concentration of 200-800 ton/year $/ \mathrm{km}^{2}$. The variation of sediment load values reflect the effect of slope and the land cover on transported sediment. The presented maps are useful to identify the sub-basin that is 
feeding the flow with high sediment concentration. These areas are to be treated with different ways for soil conservation to reduce erosion from these sub-basins. The average annual sediment load for the considered period from the whole watershed was 124.6 ton, while the total sediment load was $2.99 * 10^{6}$ ton which is equivalent to about $2.4 * 10^{6} \mathrm{~m}^{3}$.

\section{CONCLUSION}

Estimation of runoff and sediment load are important factors in operation schedule and maintenance of the dams. In case of limited filed measurements of runoff and sediment, simulation models can considered for this purpose. Soil and Water Assessment Tool (SWAT) was applied to estimate the annual runoff and sediment load of Duhok Dam watershed in north of Iraq. The model was calibrated and validated based on available field measurements, which results in good agreement. The resultant average annual runoff and sediment load of applied model for considered period 19882011 are $14.3 \mathrm{MCM}$ and $124.6^{*} 10^{3}$ ton respectively. Maps of sediment yield per unit area were presented for each sub watershed to identify the sub basins of high sediment yield. Those maps can be considered to identify the sub basins of high sediment yields to apply any method of soil stabilization if required to reduction the sediment yields.

\section{REFERENCES}

Al-Ansari, N.A. \& Knutsson, S. 2011. Toward prudent management of water resources in Iraq. J. of Advance Science and Engineering. Research 1: 53-67.

Al-Ansari, N.A., Ali, A. \& Knutsson, S. 2014. Present conditions and future challenges of water resources problems in Iraq. J. of Water Resources and Protection. 6(12): 1066-1098.

Al-Ansari, N.A., Ali, A. \& Knutsson, S. 2015. Iraq water resources planning: perspectives and prognoses. ICCCE, XIII International Conference on Civil and Construction Engineering, Jeddah, Saudi Arabia, 26-27 January, 2015: 2097-2108.

Al-Ansari, N.A. 1998. Water resources in the Arab countries: Problems and possible solutions. UNESCO International conf. (Water: a looming crisis), Paris: 367-376.

Al-Ansari, N.A. 2013. Management of water resources in Iraq. Perspectives and Prognoses, J. of. Engineering, 5(8): 667-684

Arnold, J.G., Srinivasan, R, Muttiah, R. \& Williams. J. 1998. Large area hydrologic modeling and assessment Part I: Model development. J. of American Water Resources Association. 34(1): 73-89.

Ashagre, B. 2009. SWAT to identify watershed management option: (Anjeni Watershed, Blue Nile Basin,
Ethiopia), Master Thesis, Cornell University, New York, USA: 121.

Baigorria, G. \& Romero, C. 2007. Assessment of erosion hotspots in a watershed: Integrating the WEPP model and GIS in a case study in the Peruvian Andes. Environmental. Modelling and Software. 22: 1175-1183.

Betrie, G.D., Mohamed, Y.A., van Griensven, A. \& Srinivasan, R. 2011. Sediment management modelling in the blue nile basin using SWAT model. Hydrology. and Earth System. Science. 15: 807-818.

Buringh, P. 1960. Soils and soil conditions in Iraq. Republic of Iraq, Ministry of Agriculture. Directorate of Agricultural Research and Projects. Soils: 322

Doughlas-Mankin, K.R., Srinivasan. R. \& Arnold, J. 2010. Soil and water assessment tool (SWAT) model: Current development and application. Trans.of ASABE, 53(5): 1423-1431.

Engda, T. 2009. Modeling rainfall, runoff and soil loss relationships in the northeastern highlands of Ethiopia, audit tide watershed, Master Thesis, Cornell University, USA: 84.

Fernandez, C.J., McCool Wu, D. \& Stockle, C. 2003. Estimation water erosion and sediment yield with GIS, RUSLE, and SEDD.J. of Soil and Water Conservation, 58(3): 128-136.

Gitas, I., Douros, K., Minakou, C., Silleos, G. and Karydas, C. 2009. Multi-temporal soil erosion risk assessment in $\mathrm{N}$. chalkidiki using a modified usle raster model, in: EARSeL e-Proceedings 8: 40-52.

Issazadeh, L. \& Govay, M. 2014. Reservoir sediment prediction in Duhok Dam using artificial neural network and conventional methods. Indian J. of Fundamental and Applied Life Sciences. 4(2): 441-446.

Jain, M., Mishra, S. \& Shah, R. 2010. Estimation of sediment yield and areas vulnerable to soil erosion and deposition in a Himalayan watershed using GIS. Current Science. 98(2): 213-221.

Kim, H. 2006. Soil erosion modeling using RUSLE and GIS on the IMHA Watershed, South Korea, Master Thesis, Colorado State University, Colorado, USA: 131.

Kim, J.G., Y. Park, D. Yoo, N. Kim, B. Engel \& S. Kim. 2008. Development of a SWAT ArcView GIS patch for accurate analysis of soil erosion and sediment yield at steep sloping watershed, in: American Society of Agricultural and Biological. Engineering. Annual International Meeting. 9: 5282-5287.

Mohammad E., Al-Ansari, N. \& Knutsson, S. 2013. Sediment delivery from right bank valleys to Mosul Reservoir, Iraq. J. of Ecology and Environmental Science. 3(1): 50-53.

Mohammed, J. 2013. Land use and cover change assessment using remote sensing and GIS: Dohuk City, Kurdistan, Iraq. International J. of Geomatic and Geosciences. 3(3): 552-569.

Mohammed, R. 2010. The impact of the man activity in duhok dam watershed on the future of Duhok Dam Lake North-Iraq. 1st International Applied Geological Congress, Department of Geology, Islamic Azad University-Mashad Branch, Iran, 26-28 April, 2010

Mustafa, Y. \&. Noori, M. 2013. Satellite remote sensing and geographic information systems (GIS) to assess changes in the water level in the Duhok dam. 
International. J. of Water Reourcess. and Environmental. Engineeing. 5(6): 351-359.

Nangia, V., Wymar. P. \& Klang, J. 2010. Evaluation of a GIS-based watershed modeling approach for sediment transport, International J. of Agricultural and Biological. Engineering. 3(3): 1-11.

Neitsch, S., Arnold, J., Kiniry, J., \& Williams, J. 2009. Soil and water assessment tool theoretical documentation version, Blackland Research Center-Texas SA, TR, 406:647.

Santos, I.D., Andriolo, M., Gibertoni, R. \& Kobiyama, M. 2010. Use of the SWAT model to evaluate the impact of different land use scenarios on discharge and sediment transport in the Apucaraninha River watershed, southern Brazil, International Association. of Hydrological. Science, 337: 322-328.

Shawul, A.A., Alamirew, T. \& Dinka M.O. 2013. Calibration and validation of SWAT model and estimation of water balance components of Shaya mountainous watershed, Southeastern Ethiopia. Hydroogy and Earth System Sciences. 10: 13955-13978.
Srinivasan, R.T., Ramanarayanan, G.A. \& Bednarz, S. 1998. Large area hydrologic modeling and assessment Part-II model application. J. of the Ameicanr. water Resources. Association. 34(1): 91-101.

Sulaiman, A. 2010. Estimating of annual sediments of Duhok Dam by using river turbidity water samples, J. of Duhok University Agricultural and Veterinary Science. 13(1): 82-89.

U.S. Department of Interior, Bureau of Reclamation. 1972. Erosion and sedimentation manual, US Department of USDA, Soil Conservation Service, National Engineering Handbook Section 4 Hydrology, Chapters 4-10.

Yang, C.T. 1996. Sediment Transport: Theory and Practice. McGraw Hill, NY: 395.

Yüksel, A., Akay, A., Gundogan, R., Reis. M. \& Cetiner, M. 2008. Application of GeoWEPP for determining sediment yield and runoff in the Orcan Creek Watershed in Kahramanmaras, Turkey, Sensors 8: 1222-1236. 